Western University

Scholarship@Western

Aboriginal Policy Research Consortium International (APRCi)

$9-2012$

\title{
Poverty, Work and Social Networks: The Role of Social Capital for Aboriginal People in Urban Australian Locales
}

Julie Lahn

Follow this and additional works at: https://ir.lib.uwo.ca/aprci

Part of the Public Policy Commons, $\underline{\text { Regional Sociology Commons, and the Social Welfare }}$ Commons

Citation of this paper:

Lahn, Julie, "Poverty, Work and Social Networks: The Role of Social Capital for Aboriginal People in Urban Australian Locales" (2012). Aboriginal Policy Research Consortium International (APRCi). 350.

https://ir.lib.uwo.ca/aprci/350 
This article was downloaded by: [University of Western Ontario]

On: 20 December 2012, At: 11:29

Publisher: Routledge

Informa Ltd Registered in England and Wales Registered Number: 1072954 Registered

office: Mortimer House, 37-41 Mortimer Street, London W1T 3J H, UK

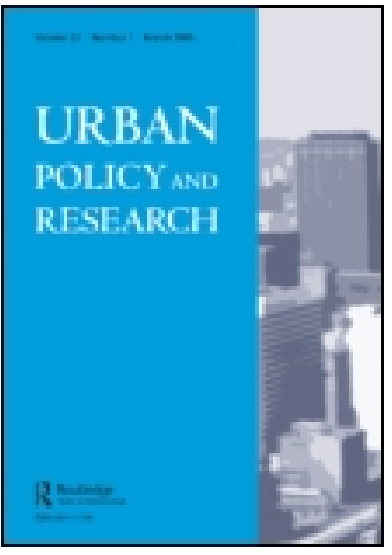

\title{
Urban Policy and Research
}

Publication details, including instructions for authors and subscription information:

http:// www. tandfonline.com/ loi/ cupr20

\section{Poverty, Work and Social Networks: The Role of Social Capital for Aboriginal People in Urban Australian Locales}

\author{
Julie Lahn ${ }^{a}$ \\ ${ }^{a}$ Centre for Aboriginal Economic Policy Research, The Australian \\ National University, ACT, Australia \\ Version of record first published: 01 May 2012.
}

To cite this article: J ulie Lahn (2012): Poverty, Work and Social Networks: The Role of Social Capital for Aboriginal People in Urban Australian Locales, Urban Policy and Research, 30:3, 293-308

To link to this article: http:// dx. doi.org/ 10.1080/08111146.2012.673483

\section{PLEASE SCROLL DOWN FOR ARTICLE}

Full terms and conditions of use: http://www.tandfonline.com/page/terms-and-conditions

This article may be used for research, teaching, and private study purposes. Any substantial or systematic reproduction, redistribution, reselling, loan, sub-licensing, systematic supply, or distribution in any form to anyone is expressly forbidden.

The publisher does not give any warranty express or implied or make any representation that the contents will be complete or accurate or up to date. The accuracy of any instructions, formulae, and drug doses should be independently verified with primary sources. The publisher shall not be liable for any loss, actions, claims, proceedings, demand, or costs or damages whatsoever or howsoever caused arising directly or indirectly in connection with or arising out of the use of this material. 


\title{
Poverty, Work and Social Networks: The Role of Social Capital for Aboriginal People in Urban Australian Locales
}

\author{
JULIE LAHN \\ Centre for Aboriginal Economic Policy Research, The Australian National University, ACT, Australia
}

(Received 29 August 2011; accepted 30 January 2012)

\begin{abstract}
In this article, I present the key findings from a project entitled "The Social Context of Indigenous Poverty". The research involved a series of interviews with Aboriginal people in urban SE Australia on issues of poverty, social capital and social exclusion. In the article I draw together Aboriginal perspectives on the meaning of poverty to reflect on the relevance of social capital concepts for understanding Aboriginal economic disadvantage and hence, the merits of policy framed in these terms.
\end{abstract}

本文阐述 “原住民贫困状态的社会环境” 课题的主要成果。该课题在澳大利亚东南部城市就贫 困、社会资本和社会排斥问题, 采访了原住民。本文将原住民对于贫困的含义的观点进行归总, 通过社会资本概念理解原住民的经济劣势地位, 说明以这些概念为 框架制定政策的好处。

KEY WORDS: Aboriginal Australia, poverty, social capital, social policy

\section{Introduction}

This article explores Aboriginal understandings of poverty in urban Australian contexts, the relevance of a social capital framing and implications for Indigenous policy. In Australia, Indigenous people have among the highest poverty rates (Saunders \& Naidoo, 2009 , p. 425). In recognition of this disadvantage, the Federal Government established the "Closing the Gaps" targets with its focus on improving statistical outcomes in life expectancy, mortality rates, early childhood education, schooling achievements and employment (see Australian Government, 2009, p. 5). Given the long-standing government emphasis on employment as a vital factor in overcoming Indigenous disadvantage (a recent example being the Federal Government's Indigenous Economic Development

Correspondence Address: Julie Lahn, Centre for Aboriginal Economic Policy Research, Copland Building \# 24, The Australian National University, ACT 0200, Australia. Fax: + 61026125 9730; Tel.: + 61026125 3166; Email: julie.lahn@anu.edu.au 
Strategy 2011-2018, Australian Government, 2011) this formed a thematic emphasis in the project: that is, what role does employment play in local definitions of poverty, and does a social capital perspective provide insights into the way Aboriginal people in urban locations access employment, or are unable to do so.

In spite of the national prominence given to the situation of remote Aboriginal communities it is widely understood in academic and policy circles that the Australian Indigenous population largely resides in urban areas (Biddle, 2009). National census statistics estimate that from 1971 to 2001, the urban-based Aboriginal population grew as a share of the total Indigenous population from 44 to 76 per cent (Taylor, 2009, p. 3). This article seeks to contribute to the imperative of engaging urban-dwelling Aboriginal populations. Research interest in Indigenous social life in urban settings has existed for several decades, particularly in relation to poverty (e.g. Reay, 1964; Rowley, 1970; Gale, 1972; Keen, 1988). Nevertheless, such work has generally been regarded as of secondary importance to research in remote Australia with the result that urban-dwelling Aboriginal people are often inadequately understood in terms of dominant analytical categories (Langton, 1981; Rowse, 2000; Prout, 2011). More recently, a strong interest in the study of Aboriginal identity in major urban centres such as Sydney is emerging (e.g. Everett, 2010; Yamanoguchi, 2010). The research I draw on here involves 60 semi-structured interviews with Aboriginal people residing in Western Sydney, New South Wales and in Shepparton, Victoria. All interviewees were identified by Aboriginal research assistants at each location.

\section{Background}

In general terms, social capital theory suggests that the more social relationships an individual is involved in, the more social capital they possess; as one scholar puts it, "the more people you know, and the more you share a common outlook with them, the richer you are in social capital" (Field, 2003, p. 1). This element—a shared common outlook—is regularly viewed as a critical component in social capital. For many theorists, mutual trust and collectively held shared values are critical to understanding both how networks of social relationships are established and also why these relationships are productive, that is, in enabling or facilitating the achievement of individual and common goals. In general terms, relatedness and shared values give rise to this resource labelled social capital.

The variety of social capital theory that appears to have exerted most influence in research about poverty has been referred to as the 'networks' version. Where people's participation in social networks is limited or constrained, and/or the networks in which they are involved are marked by low levels of common outlook-interpreted as low levels of trust-then such people are sometimes referred to as being 'network impoverished' (see the review by Quillian \& Redd, 2008). In other words, such individuals are regarded as possessing low levels of social capital (e.g. Green, 2006). The suggestion is that the more network impoverished a person is, the more likely they are to also be experiencing material impoverishment. General claims of an association between low levels of social capital and low levels of income are frequently extended into claims of causality-that low levels of social capital are a significant or major cause of poverty; where a person's social networks are neither extensive nor varied one can expect a higher incidence of economic disadvantage.

In the Australian context, social capital has seldom been linked to poverty in such direct terms. More often it is associated with broader concerns of community well-being, in which ideas of exclusion and deprivation are also prominent. Between 2000 and 2009 
social capital occupied a key position in the Department of Families, Housing, Community Services and Indigenous Affairs' (FaHCSIA) "Stronger Families and Communities Strategy", which had an explicit goal of "expanding social capital and the capacity of members of local communities to resolve some problems themselves" (Johnson et al., 2005; Muir et al., 2009). More recently the idea of 'social inclusion' has been positioned discursively as the driving principle within Australian policy frameworks aimed to address problems of disadvantage, discrimination and poverty, whether in Indigenous or nonIndigenous contexts. The general emphasis in this idea is with obstacles or deficiencies that prevent members of disadvantaged groups from improving their situation.

In their current application in Australia, the twinned conception of social inclusion/exclusion tends to be positioned as providing a greater degree of conceptual sophistication than social capital in the analysis of poverty and inequality by highlighting multiple dimensions of disadvantage and their evolution over time (Hunter \& Jordon, 2010, p. 260). One persistent shortcoming in social capital theory has been its difficulty in taking account of the ways in which the relationships and networks it generally lauds could act also to exclude. Research has suggested that externally constraining factors (such as discrimination) likely play an equal or more important role in producing racialised differences in poverty than social capital (Quillian \& Redd, 2008). The current policy prominence given to notions of social inclusion/exclusion may well offer advantages in engaging with this issue, clearly one of critical relevance to Indigenous disadvantage. But rather than being displaced by the new emphasis on inclusion/exclusion, social capital has generally been incorporated within a Social Inclusion framework.

Several research reports created for the Australian Government (e.g. Hayes et al., 2008; Australian Social Inclusion Board, 2009; Vinson, 2009a, b) all contain clear references to social capital and link it to social inclusion/exclusion. For example, 'inclusive and resilient' communities are claimed to possess "a high level of social capital. That is, mutual trust, social norms, participation and social networks" (Australian Social Inclusion Board, 2009, p. 5). In addition, "the extent and quality of social networks" is highlighted as a key dimension of social exclusion, while "limited social connectedness (social capital)" is linked to disadvantage and deprivation (Hayes et al., 2008, pp. 7, 9). Further, "A socially inclusive society marked by widespread participation tends to be high on "social capital", which comprises, in part, "growth of a culture of reciprocity and trust" (Vinson, 2009b, p. 8). Finally, in a later paper, Vinson (2009a, p. 5) links "containment of the ill-effects of financial and other deprivations" to "building "collective efficacy", which in turn involves "developing connections and trust between people and between organizations; developing the confidence and ability to identify ways of promoting the common good; and securing the resources, internal and external, needed to pursue them". "Collective efficacy" conceived in this sense is practically synonymous with social capital, linked once again to the "capacities needed to sustain community well-being" (p. 5).

An emphasis on social networks and on relationships between people as important resources linked to both individual and community levels of well-being and health, and the critical role of trust and reciprocity, are all fundamental insights drawn from social capital theory (Berry, 2009; Baum et al., 2011, p. 38). The continuing influence and now largely embedded nature of social capital theory in contemporary policy thinking is evident in such documents. Indeed, it has become a given that social capital is a positive attribute that individuals and communities need to have, and any identified lack is a cause for concern (Blokland \& Savage, 2008). In the current language of addressing disadvantage, to be 'socially 
included' one must have, among other attributes, adequate stocks of social capital. Social capital has shifted from being the focus of policy discussion concerning situations of disadvantage to an integrated element of policy frameworks, from 'debate' to 'doxa'.

A problem in this transition is that the utility of such theoretical perspectives in understanding and potentially addressing disadvantage require careful and ongoing questioning. The conceptualisation of social inclusion/exclusion, particularly in respect of Australian indicators that might monitor policy interventions and evaluate outcomes, remains in its very early stages. Certainly, it proved quite difficult to develop concrete, tangible evidence of social capital that lent itself to quantitative analysis (see, e.g. Daniere et al., 2002). One of the consistent difficulties involved a lack of consensus not only about how it ought to be measured, but the possibility, desirability and practicality of doing so (e.g. Van Deth, 2003; Hunter, 2004; Mouw, 2006; van der Gaag \& Webber, 2008). It is likely that emerging concepts of social inclusion/exclusion will suffer from similar issues. But the problems of defining and operationalising social capital generated a substantial research effort, involving key Federal Government funded institutions such as the Australian Institute of Family Studies (e.g. Winter, 2000; Stone, 2001; Stone \& Hughes, 2002) and the Australian Bureau of Statistics (e.g. Australian Bureau of Statistics, 2004; Biddle et al., 2009). In part, the research featured here sought to test these approaches in the context of field-based research with urban-dwelling Aboriginal people.

\section{Social Capital and Aboriginal People}

Early in Labor's first term in office FaHCSIA highlighted a strategic concern to "tackle Indigenous disadvantage" by "promoting economic participation and reducing welfare dependency" (Macklin, 2008). Seeking to further that aim, on 20 October 2011 the Federal Government launched their "Indigenous Economic Development Strategy 2011-2018" (Australian Government, 2011). This multi-departmental strategy was launched with the Minerals Council of Australia and co-badged with the "Closing the Gap" logo. Among its aims is a clear desire to encourage increased private sector employment opportunities with 'governments' encouraging Indigenous economic participation by creating connections with business and community organisations. In doing so, the Federal Government appears to be seeking to strengthen government and private sector networks for use by Aboriginal people because existing Indigenous networks are insufficient to ensure economic participation; they need access to other, new networks in order to gain greater access to employment.

It is important to note here that the relationship of social capital to disadvantage and poverty often carries normative assumptions about the shape and character of an individual or community's social networks. A standard approach (derived from Woolcock, 2001, which is not far removed from Putnam, 1993) divides social capital into three parts as a means to capture a more complete range of social networks, making the concept more useful (especially in field-based research). These are bonding, bridging and linking:

Bonding social capital refers to close social ties between people in similar situations such as immediate family, good friends or close neighbours;

Bridging social capital consists of looser ties of like persons, for example, workmates or more causal friends, who can assist people in one network get access to the resources of another network; 
Linking social capital comprises relationships with people in dissimilar situations, such as those entirely outside a community. (Woolcock, 2001, pp. 13-14)

These relationships are seen as enabling access to a far wider range of resources in the community.

Within normative approaches to social capital, individuals ideally possess a balance between all three forms in order to maximise their access to the potential benefits of a range of diverse networks. One claim that repeatedly surfaces in debates concerning Indigenous economic disadvantage is that Aboriginal culture demands the expending of considerable effort in maintaining relations within extended kin networks at the expense of other forms of relationships. In the language of social capital, this might be glossed as an over-emphasis on bonding social capital at the expense of bridging or linking forms, which limits the possibility of making a much wider range of resources potentially available to individuals from within and beyond their community, potentially increasing social exclusion.

Considering the long-standing influence of social capital in policy and research circles, it is surprising that there have been few projects working explicitly with understanding or measuring social capital in Aboriginal contexts. From these existing studies, there are a number of insights to be gleaned, beginning with two large statistical studies using national surveys, the 1994 and 2002 National Aboriginal and Torres Strait Islander Social Studies (NATSISS). The first of these studies found that high unemployment was associated with low social capital and high rates of social exclusion, but also that being employed does not necessarily increase one's social capital; indeed, working may actually diminish certain forms such as that involved in familial or bonding networks (Hunter, 2000). The second study (Vurens van Es \& Dockery, 2008) concluded that the size and diversity of Indigenous people's social networks (i.e. social capital) was positively linked to labour market outcomes. However, as in the first study, the authors could not identify relations of causality, only association. In general terms, a relationship appears to exist between social capital and employment, but the precise nature of this relationship is unknown.

Other studies that explore the nature of social capital among Indigenous people include several qualitative studies based variously on a combination of focus groups, workshops and individual interviews with people involved in community organisations and business. These studies reflect on the relevance of the concept in specific social contexts. A study of social and institutional capital conducted in the remote Northern Territory community of Wadeye by Memmott and Meltzer (2005) tested some social capital indicators and found concepts like 'trust' and 'reciprocity' to be broadly applicable to Aboriginal contexts, a finding also shared by Christie and Greatorex (2004). However, Memmott and Meltzer (2005) also suggested that social networks, rather than being characterised as formal or informal (a common distinction also appearing in the literature), social networks are characterised predominantly as either Aboriginal or non-Aboriginal. A study by Aboriginal academic Dennis Foley (2008) in (unnamed) urban locations found that the social networks of Indigenous business people were similarly framed, and moreover that interviewees felt efforts to access diverse networks were largely unsuccessful, circumscribed by external dynamics of exclusion. Certainly trust and civic participation, when measured quantitatively, are relatively low among Indigenous people (e.g. Gilles et al., 2004).

Another urban study in Brisbane similarly highlighted Indigenous/non-Indigenous divisions in social capital networks (Brough et al., 2006; see also Brough \& Bond, 2009). Working with Putnam's distinction of bonding and bridging forms of social capital, 
the Brisbane study argued that for Aboriginal people, developing bridging networks with non-Aboriginal people entails crossing a significant social/cultural gulf. The authors state that if there were no such gulf or space between [bonded and bridged communities], then "claiming a strong Aboriginal identity as well as an equal socioeconomic position in Australian society would not be so difficult" (Brough et al., 2006, p. 406). They argue that rather than focusing on whether Aboriginal people have adequate or inadequate levels of social capital, policymakers should focus on the "exclusionary practices [that] are the drivers of inequality" and which have helped to create distinct bonded and bridged communities separated by their Indigenous and non-Indigenous status.

These qualitative studies each in their own way make an important plea for bringing Aboriginal viewpoints into the conversation concerning social capital and for that matter exclusion/inclusion. Hunter and Jordan note the need to accommodate Indigenous cultural needs and preferences in such conceptions: "the term social inclusion begs the question of what people are to be included in?" (2010, p. 260). The development of coherent and inclusive notions of equality and difference (rather than equality or difference) requires critical reflection on the degree to which a veiled normativity operates through ideas of social capital and social inclusion/exclusion, particularly in conceiving of disadvantage, which may undermine the laudable goals of the policy programmes in which they have a prominent place. The following research explores this concern in examining the application of social capital framings to Indigenous understandings of poverty and experiences of work.

\section{The Social Context of Indigenous Poverty}

\section{Research Locales: Shepparton and Western Sydney}

Shepparton is a large regional centre in south-eastern Australia, located about two hours from Melbourne. The area is home to a significant community of Aboriginal people, many of whom identify as Yorta Yorta. The Aboriginal people who live in the area are sometimes referred to as the Goulburn Valley Aboriginal Community. Previous research in the area has presented Shepparton as a locale suffering psychosocial stresses linked to poor Indigenous/non-Indigenous relations (Bourke \& Geldens, 2007; Tynan, 2007). The area is also well known in policy circles as a Council of Australian Governments (COAG) trial site. Though Shepparton is a locale where Indigenous disadvantage is significant (see Lahn, 2008 for a statistical summary), Shepparton is also a place where Aboriginal enterprise is clearly visible and Indigenous leadership appears active in promoting locally led approaches to overcoming that disadvantage (Cutliffe, 2005). The largest Indigenous population in Victoria outside of Melbourne resides in Shepparton. The Australian Bureau of Statistics 2006 Census of Population and Housing estimates that 3.34 per cent or 1819 people in the Greater Shepparton area are Indigenous.

Sydney is home to a much larger population of Indigenous people. The 2006 Census estimated that 46886 Indigenous people reside there. This equates to roughly threequarters of the Indigenous population of the Northern Territory (Biddle, 2012, p. 75). Sydney's Indigenous population is also generally subject to high rates of mobility particularly where young single people (15-24 years) migrate in and families migrate out (Prout, 2008). Sydney as a whole is a place of extremes with areas of relative advantage within Inner Sydney and disadvantage such as that found in Western Sydney (e.g. Peel, 2003; Morgan, 2006). Even among this project's Western Sydney research 
sites, there is diversity with Penrith and Mt Druitt, for example, showing some statistical differences despite their relative proximity. Compared with Mt Druitt, Penrith has greater proportions of Indigenous home ownership, more people with post-school qualifications, higher employment rates and higher incomes (2006 Census of Population and Housing). In relation to Mt Druitt and Penrith, Shepparton lies somewhere in between with indicators such as owning/buying a house and employment rates being clear areas of divergence.

\section{Methodology}

The main data consists of extended interviews with Aboriginal people. I employed locally resident Aboriginal research assistants to help identify, locate and interview participants. Together, we conducted 60 interviews divided evenly between the two regions. Locations I visited in Western Sydney included the suburbs of Penrith, St Mary's and Mt Druitt.

Despite extant critiques of the difficulties involved in measuring social capital, I utilised a small number of quantitative measures in combination with an overtly qualitative, interpretive approach. Given the project's dual emphasis on social capital and on poverty, I took particular note of two Australian research projects: one was the Australian Institute of Family Studies' project entitled "Families, Social Capital and Citizenship" that ran for a few years from the late 1990s and spawned a survey instrument for measuring social capital (as mentioned earlier). I utilised their measures for bridging and linking social capital. However, to measure bonding social capital, I designed a unique measure to capture the nature and extent of bonding through reciprocity. Reciprocity is often linked in the anthropological literature to the idea that Aboriginal sociality is embedded in a moral economy (Peterson \& Taylor, 2003). Aboriginal explanations of identity generally entail having a family to belong to, as evidenced in the movement of money, goods and services that sustain and reproduce relations within extended familial networks. This characterisation has been identified across a range of locations (e.g. Schwab, 1995; MacDonald, 2000) hence it was used in this study as a proxy measure for bonding.

The other study influencing my work was a research project entitled "Left Out and Missing Out: Towards New Indicators of Social Exclusion and Material Deprivation" conducted through the Social Policy Research Centre at the University of New South Wales, which explored new indicators of poverty and also involved a small sample of Aboriginal respondents (see Saunders et al., 2007). I replicated a number of the key questions that appeared in these two studies, including subjective measures of poverty, income, financial stress and social networks. The following is a description of the key qualitative results emerging from the project that consider the relation of social capital and poverty and support critical reflections on the application of notions of social capital in urban Indigenous contexts.

\section{Poverty and Families}

The importance of family in the lives of Aboriginal people emerged as a key theme in the interviews, reinforcing an established insight from the anthropological literature concerning what it means to be Aboriginal (see above). The value of work, money and even home ownership was consistently articulated in terms of importance within family or community life, rather than individual needs, aspirations or socio-economic advancement. 
As one woman said:

No yeah I'm a real family person I love my family anyone hurts em look out mate and I think that's with all Koories we're real protective of our families.

A different participant, considering the difference between relations with family and workmates, suggests that:

Family's always gonna be there for ya. You know if you do something wrong your family's not gonna look down at ya but other people might just totally turn you away.

These two comments, from two different participants, were typical:

I don't need [to buy] a house, I got no children so don't want one.

I wanna [buy a] house for me boys-that's the main option, the big goal.

I found a marked reluctance to identify as being poor, even among participants whose incomes were close to or below the national poverty line ${ }^{1}$ at the time. In direct contrast, one of the key findings of a 2007 FaHCSIA-funded study titled, "Income Poverty, Subjective Poverty and Financial Stress" suggests: "Indigenous status was strongly associated with increased odds of being in subjective poverty" (Marks, 2007, p. ix). One explanation may be that the presence of Aboriginal research assistants during interviews had an inhibiting effect on the informants' willingness to describe themselves as poor, because of the stigma I previously referred to. Another possibility is that the kind of survey methodology used to produce the data involved in the FaHCSIA study (i.e. the methodology employed in the Household, Income and Labour Dynamics in Australia [HILDA] survey in 2000 and 2001) elicited a different response-that Aboriginal people filling in a formal, institutional questionnaire may 'read' the cultural expectations involved and respond accordingly.

In concrete terms, ideas of poverty were primarily associated with the situation of having 'no roof over your head' (lack of shelter) or 'no chance of a feed' (lack of food). Even when faced with financial difficulty, participants maintained that they were able to meet these two critical needs through family and friends within the Aboriginal community. Again a couple of typical responses:

We're not poor. We've got a roof over our head and food on the table. Food and housing is a bottom line.

I'm not poor but I can't afford luxuries. We can always have a feed, we've always got family to feed us.

No cause I'm not begging for food, begging for clothes on my back and stuff from organisations, like Salvation Army, and that kind of thing. I mean I've asked them for help in the past, but not every day.

The data suggests that to be poor in Aboriginal terms is to have no familial networks to call upon, especially when in need of food or shelter. Hence, those individuals whose incomes 
were low but had networks of support did not feel justified in describing themselves as poor. In the language of social capital, this conception of poverty could be said to represent a situation of limited bonding social capital, for instance, networks of close ties to family and friends able to be drawn upon when required.

Again, the prominence and importance of such ties were seen as defining of Aboriginal social life, as one participant observed:

I honestly don't know how youse whitefullas survive on ya own ... It's ridiculous you know, ya see people who won't ask their parents for anything and ya think what's wrong with ya-if you can't ask them, who can ya ask?

It followed that there was a tangible moral dimension to the idea of poverty, thus defined. To have no familial networks to call upon, despite being Aboriginal, calls into question the conduct of the individual concerned who must in some way have endangered the persistent ties that lie at the heart of Aboriginal identity and sociality. Those participants who stated that they knew Aboriginal people who could be considered poor, invariably linked such status to problems with excessive drinking and gambling, leading these people to shift their attentions to those social networks associated with these activities and/or a situation where their relatives and friends eventually become reluctant to assist them.

\section{Work and Families}

A corollary of the importance placed on bonding social capital in Aboriginal life was that participants did refer to regularly experiencing difficulties balancing the demands of activities outside familial networks, such as employment. Almost every interviewee involved stated that they had felt compelled to give up a job for family-related reasons, such as the obligations surrounding deaths, elderly relatives needing care, etc. This meant that work in Aboriginal organisations or with other Aboriginal people was highly prized because of the greater scope for shared values:

Working with your own people, we understand each other, where we come from, where we've been and our cultural backgrounds. Mainstream haven't got a clue. Say if one of our people died in our community, as part of our community, we go, we go to the funeral. Mainstream, you've gotta cut it out of the paper [the funeral notice], give it to them, go through all that rigmarole. With Koori organisations, when somebody passes away they know everyone goes to support their families. Whitefellas are about the dollar, the dollar, the dollar, the 9 to 5 factor. That's it.

Importantly, in addition to being key sources of material resources (money, food, transport, accommodation, caring for kids), familial networks also act as an 'employment network'. Statistical research has found that Indigenous people do seek information about jobs from friends and family more than non-Indigenous people (Hunter \& Gray, 2006) although the methods used to find employment opportunities aren't related to employment outcomes when external constraints are taken into account (Gray \& Hunter, 2005).

The vast majority of our participants in this study had found their current or most recent job through family networks. A key contrast to mention here comes from a US study concerning social capital and racial poverty gaps. The authors conclude that "non-whites 
have networks that are comparable in size to whites and that include many employed persons, contrary to any extreme form of social isolation" but refer to research that suggests "while poor blacks have job contacts with employed persons, their contacts are often reluctant to recommend them to current employers because they fear that the worker they recommend will do a poor job, reflecting badly on them" (Quillian \& Redd, 2008, p. 177). This raises an interesting issue - that under some circumstances it may be difficult to access benefits through existing networks, or that the willingness of network members to help is more crucial than the size (or composition) of networks. That Aboriginal familial networks in my study did seem to function effectively in delivering a 'job search benefit' perhaps points to a higher level of shared social values in such networks, and once again raises the possibility that even if Aboriginal people could gain more diverse networks (i.e. increase bridging and linking forms of capital) there is no guarantee such networks would deliver benefits.

In this study, familial networks were found to be particularly critical to finding some of the more desirable forms of employment, those involving an Aboriginal boss or manager. In this sense, the assumption that greater resources (such as improved access to employment) necessarily become available to individuals through building all three forms of social capital must be modified to take into account the specific character of the resources sought, the likelihood of their mobilisation via each form of social capital and cultural differences in the scope of the resources available. Moreover, among the Aboriginal people I interviewed, bonding forms of social capital appear to offer a far more extensive range of potential resources than might be expected for most non-Indigenous Australians. Bonding networks offered both 'poverty-proofing' (at least, in a subjective sense) and regularly facilitated access to employment. I suspect that neither would be true for non-Indigenous bonding (or at least, there would be a great deal of variability, not the consistency and reliability reported by those people we interviewed). ${ }^{2}$

So while the demands involved in bonding social capital in Aboriginal familial networks can clearly problematise aspects of (mainstream) employment, this study suggests the claim that 'excessive bonding exacerbates disadvantage' is far too simplistic. Rather than distracting from efforts to accumulate other forms of social capital (and therefore creating or compounding disadvantage) Aboriginal family networks constitute a critical resource that assist people in avoiding poverty (for example, by providing access to paid work, or at least information about jobs that are available, as well as guaranteeing basic material needs).

\section{Families and Social Capital}

Aboriginal familial networks also act to tie individuals with abundant forms of bridging and linking social capital (such as people who play a prominent role in establishing and maintaining funding for an Indigenous organisation) to individuals with much less. The general emphasis on bonding social capital in Aboriginal community life could be said to act to facilitate individual access to the resource benefits of bridging and linking forms of social capital. For Aboriginal people, bonding is a potential route to the benefits generated through bridging and linking (and sometimes to bridging and linking itself, where employment in an Aboriginal community organisation, for example, offers opportunities to establish relationships outside their community). 
It follows that comparative measures of bonding, bridging and linking social capital were not good predictors of the degree of disadvantage experienced by participants (e.g. how much money people earned and whether people were employed or not). What this means is that there was a variety of income and employment levels among those who were low in bridging and linking forms of social capital - there seemed to be no straightforward predictive value. This reinforces earlier findings in the poverty literature that suggest social capital may be too focused on formal networks (e.g. membership of organisations, political parties, institutions, etc), as a result failing to give sufficient attention to the ways in which informal networks (such as family and friends) can work to people's economic advantage. My view is that this does constitute a key shortcoming of social capital, further aggravated through the smuggling in of implicit Western assumptions concerning the likely scope of bonding resources to Indigenous social contexts.

\section{Bringing it Together: Families, Social Capital, Work and Poverty}

Clearly, there are potential shortcomings in relying on one's network of family and friends (bonding social capital) as a primary employment strategy. Among those participants who were currently unemployed, it was common to find that the bulk of their family and friends were also unemployed. Similarly, participants occupying low-income positions often found out about such work from family and friends who also hold jobs where the pay is low. These individuals may benefit most from targeted assistance to find employment, or better employment, as their familial network will be less useful to them in this regard.

One of the dangers of bringing ideas of social capital and poverty together is that notions of social capital can be used to create an individual deficit type of model that blames the disadvantaged for their situation: individuals are poor because they have failed to accumulate sufficient social capital, or to balance their accumulation efforts across all three necessary types. However, significant factors operate externally that are not revealed by social capital such as employer prejudice, or wider forms of institutionalised discrimination.

An international meta-review of the literature supports this view, finding the evidence regarding the relation between poverty and social capital to be mixed; that while social capital is important to the relation between job seeking strategies and poverty, discrimination plays an equal or more important role in producing racialised differences in poverty than social capital (Quillian \& Redd, 2008).

With such externally constraining factors such as discrimination in mind, a general emphasis on bonding forms of social capital could be viewed as a sensible strategy; in addition to providing fundamental safeguards against extreme forms of poverty, an emphasis on bonding maximises the resource flow-on from individuals in familial networks who manage to attain the most resource-rich positions.

\section{Implications for Urban Indigenous Policy}

The critical literature in relation to concepts of social capital is perhaps nearly as large as the literature that utilises the idea. There is a standard array of well-rehearsed criticisms, both among those who apply competing visions of the concept, and amongst those who attack its use and theoretical underpinnings. Depending on the sets of assumptions that one brings to social theory (philosophical, political, epistemological) some of these general critiques are quite damning. 
In the context of my own project, the importance of identity needs, for example, loomed large in my thinking; if social capital is fundamentally concerned with relationship networks as productive, as enabling or facilitating the achievement of individual and common goals, then what about identity? Is this not a goal, and ought we consider the mobilisation of identificatory resources through social networks? In which case in Aboriginal terms, bonding social capital again looms very large indeed-this is where the major resources for Indigenous identity are to be found. And in relation to periodic references to dysfunctional culture and mainstreaming etc., is the implicit suggestion that Indigenous people need more bridging and linking forms of social capital as against bonding simply a way of suggesting that Aboriginal difference is the problem?

In arriving at the 'shared values' and 'common outlook' that is a critical aspect of productive social networks, how 'shared' and how 'common' would such values be in networks involving both Indigenous and non-Indigenous people? Would there be a process of meeting in a 'cultural middle-ground', or will it be Indigenous people who find themselves under significant pressure to give ground to dominant non-Indigenous social values ("the dollar, the dollar, the dollar")?

Nonetheless, social capital is currently embedded in policy approaches aimed at reducing Indigenous disadvantage, a situation likely to continue at least in the foreseeable future, so in terms of the parameters addressed in this project it is critical to address the question: is social capital useful in Indigenous policy contexts? My answer is, in part-yes. The idea of social capital encourages attention to a range of critical intangible aspects of social life (e.g. reciprocity, trust) that may be relevant to material disadvantage and economic exclusion. Placing value on the importance of relationships in social life and their interaction with wider social structures potentially resonates with core social values and understandings held by Aboriginal people. However, the critical issue in relation to influencing policy direction "is not whether a concept can be applied loosely, but whether it leads to new insights when applied finely" (Field, 2003, p. 43). In this respect, the concept of social capital has major shortcomings, in particular: (a) only providing part of the picture of the factors at play in poverty and (b) difficulties in cross-cultural applicability where different cultural values may emphasise specific forms of social capital (such as bonding social capital, e.g. familial networks), which may in fact represent positive advantages for the groups concerned.

However appealing as generalised concepts, the envisaged resource content of bonding, bridging and linking need to be tested and adapted to specific socio-cultural settings before being utilised by policymakers. And certainly, any approach that envisages a zero sum interpretation of social capital, where each individual requires equal stocks of each of the three types of social capital, seems misguided. This involves close attention to the texture of social life, rather than the application of a priori frameworks of measurement.

At the level of Indigenous familial networks, or Indigenous communities, it may be sufficient for relatively few individuals to possess connections with diverse and resourcerich networks beyond Aboriginal community life (e.g. business and government), that is, possessing a significant level of linking social capital, in order for the associated resources to flow to a range of other people with whom that individual shares social ties. While the language of policy documents in this field tends to emphasise 'community', the targets for intervention measures are often individuals. The slippage between community and individual is present in the social capital literature also, which is undecided on the question of which forms the best focus for assessing social capital. If policymakers are keen to use social capital in relation to Indigenous poverty in urban Australia, it would be of value 
to avoid focusing on systems of measurement that assume the universal and equal relevance of all three forms at the individual level, or utilise abstract ideas of locational communities, and consider instead methods that explore the operation of social capital at the level of familial networks, which Aboriginal people themselves consistently emphasise as the most important and distinguishing feature of their lives.

Social capital theory is good to think with, hence numerous government departments have chosen to work with conceptions of social capital. It seems to make intuitive sense that social networks and social relationships should be recognised as having value. However, it will only hold practical analytical merit if adapted to suit Indigenous circumstances and aspirations.

\section{Acknowledgements}

Wholehearted thanks to those people who participated in interviews and to the research assistants and organisations that facilitated the research process, the Strategic Policy and Planning Unit, Shepparton, and Muru Mittigar, Penrith, and the then named Daruk Aboriginal Community Controlled Medical Service, Mt Druitt. A version of this article was presented in the Centre for Aboriginal Economic Policy Seminar Series, at The Australian National University. The comments received in that forum were helpful in the redrafting process as were the comments offered by UPR's two reviewers. The author also benefited from conversations with Dr Boyd Hunter and Professor John Taylor (both of ANU).

\section{Notes}

1. Though poverty is now largely understood as multidimensional and a poverty line as a unidimensional instrument, the use of a poverty line indicator is still regarded as a useful tool providing "the statistical foundation on which other methods of measuring deprivation and social exclusion can build" (Saunders et al., 2008, p. 1).

2. To assess the overall effectiveness of such a strategy that aims to utilise bonding social capital networks to access desired work in Indigenous community organisations, it is necessary to grasp the size of what has been termed the 'Indigenous sector' (Rowse, 2002). This important sector emerged out of the self-determination era. Unfortunately, it is not possible to quantify the current size of this potentially large sector (Taylor \& Hunter, 1997). In national statistics, the sector is routinely embedded within either public or private sector categories. There has been a single opportunity to quantify this group using the 1994 National Aboriginal and Torres Strait Islander Survey (NATSIS) (Taylor, 2006). The NATSIS data is arranged by Aboriginal and Torres Strait Islander Commission (ATSIC) regions and doesn't offer estimates for my specific study locations, Shepparton and Western Sydney, but its national estimates show that 2.6 per cent or $n=1700$ of the total number of Indigenous persons employed were working in community organisations (Australian Bureau of Statistics, 1995). Oddly, in the same year that the 1994 NATSIS was conducted, 2600 Indigenous organisations were registered with the Office of the Registrar of Indigenous Corporations (Commonwealth of Australia, 2008). In simple terms, this means that the number of registered Indigenous organisations was larger than the number of Indigenous people employed by Indigenous community organisations (as counted by NATSIS). In these terms the 1994 NATSIS arguably represents an underestimate of the Indigenous sector. The nature and potential size of the Indigenous sector is the subject of ongoing research by the author.

\section{References}

Australian Bureau of Statistics (1995) National Aboriginal and Torres Strait Islander Survey 1994: Detailed Findings, Catalogue No. 4190.0 (Canberra: Australian Government Publishing Service).

Australian Bureau of Statistics (2004) Measuring Social Capital: An Australian Framework and Indicators, Information Paper 1378.0 (Canberra: Commonwealth of Australia).

Australian Government (2009) Closing the Gap on Indigenous Disadvantage: The Challenge for Australia (Canberra: Australian Government).

Australian Government (2011) Indigenous Economic Development Strategy 2011-2018 (Canberra: Australian Government). 
Australian Social Inclusion Board (2009) Building Inclusive and Resilient Communities (Canberra: Australian Government).

Baum, F., Putland, C., MacDougall, C. \& Ziersch, A. (2011) Differing levels of social capital and mental health in suburban communities in Australia: did social planning contribute to the difference?, Urban Policy and Research, 29(1), pp. 37-57.

Berry, H. (2009) Social capital and mental health among Aboriginal Australians, new Australians, and other Australians living in a coastal region, Australian e-Journal for the Advancement of Mental Health, 8(2), pp. 1-13.

Biddle, N. (2009) Indigenous gaps in the city, Indigenous Law Bulletin, 7(14), pp. 16-19.

Biddle, N. (2012) First peoples in Australia's first city: the geographic, demographic and economic status of the contemporary Aboriginal population of Sydney, Unpublished manuscript.

Biddle, N., Davis, E., Myers, J. \& Dodhy, R. (2009) Exploring Measures of Low Social Capital, ABS Catalogue No. 1351.0.55.024 (Canberra: Australian Bureau of Statistics, Commonwealth of Australia).

Blokland, T. \& Savage, M. (2008) Networked Urbanism: Social Capital in the City (London: Ashgate).

Bourke, L. \& Geldens, P. (2007) Perceptions of reconciliation and related Indigenous issues among young residents of Shepparton, Australian Journal of Social Issues, 42(4), pp. 603-621.

Brough, M. \& Bond, C. (2009) Little theory, big plans: social capital and community building in Aboriginal Australia, in: G. Woolcock \& L. Manderson (Eds) Social Capital and Social Justice: Critical Australian Perspectives (Darwin: Charles Darwin University Press).

Brough, M., Bond, C., Hunt, J., Jenkins, D., Shannon, C. \& Schubert, L. (2006) Social capital meets identity: Aboriginality in an urban setting, Journal of Sociology, 42(4), pp. 396-411.

Christie, M. \& Greatorex, J. (2004) Yolngu life in the Northern Territory of Australia: the significance of community and social capital, The Asia Pacific Journal of Public Administration, 26(1), pp. 55-69.

Commonwealth of Australia (2008) FaHCSIA Annual Report 2007-2008 (Canberra: Department of Families, Housing, Community Services and Indigenous Affairs).

Cutliffe, T. (2005) Measuring success: sharing power and accountability with Shepparton's Aboriginal people, Unpublished Report, The Eureka Project, Melbourne.

Daniere, A., Takahashi, L. \& NaRanong, A. (2002) Social capital, networks and community environments in Bangkok, Thailand, Growth and Change, 33(4), pp. 453-484.

Everett, C. (2010) Urban Aboriginal ceremony: when seeing is not believing, in: F. Peters-Little, A. Curthoys \& J. Docker (Eds) Passionate Histories: Myth, Memory and Indigenous Australia (Canberra: ANU E Press).

Field, J. (2003) Social Capital (London: Routledge).

Foley, D. (2008) Does culture and social capital impact on the networking attributes of Indigenous entrepreneurs?, Journal of Enterprising Communities: People and Places in the Global Economy, 2(3), pp. 204-224.

Gale, F. (1972) Urban Aborigines (Canberra: Australian National University).

Gilles, M., Larson, A., Howard, P. \& Wheatland, B. (2004) Health, Trust and Social Capital in a Rural Town: Preliminary Findings from the November 2003 Survey (Geraldton: Combined Universities Centre for Rural Health).

Gray, M. \& Hunter, B. (2005) The labour market dynamics of Indigenous Australians, Journal of Sociology, 41(4), pp. 389-408.

Green, M. (2006) Representing poverty and attacking representations: perspectives on poverty from social anthropology, Journal of Development Studies, 42(7), pp. 1108-1129.

Hayes, A., Gray, M. \& Edwards, B. (2008) Social Inclusion: Origins, Concepts and Key Themes (Canberra: Commonwealth of Australia).

Hunter, B. (2000) Social Exclusion, Social Capital, and Indigenous Australians: Measuring the Social Costs of Unemployment, CAEPR Discussion Paper No. 204 (Canberra: Centre for Aboriginal Economic Policy Research, Australian National University).

Hunter, B. (2004) Taming the Social Capital Hydra? Indigenous Poverty, Social Capital Theory and Measurement, CAEPR Topical Issue No. 8 (Canberra: Centre for Aboriginal Economic Policy Research, Australian National University).

Hunter, B. \& Gray, M. (2006) The effectiveness of Indigenous job search strategies, Economic Record, 82(256), pp. $1-10$.

Hunter, B. \& Jordan, K. (2010) Explaining social exclusion: towards social inclusion for Indigenous Australians, Australian Journal of Social Issues, 45(2), pp. 243-265.

Johnson, D., Headley, B. \& Jensen, B. (2005) Communities, Social Capital and Public Policy, Policy Research Paper No. 26 (Canberra: Australian Government Department of Family and Community Services). 
Keen, I. (1988) Being Black: Aboriginal Cultures in 'Settled' Australia (Canberra: Aboriginal Studies Press).

Lahn, J. (2008) Aboriginal people, money and financial literacy: Shepparton in a national context, in: B. Traynor, S. Blair \& V. Schubert, My Moola: 'Opening Financial Pathways Program' evaluation report. Unpublished Report, The University of Melbourne, School of Philosophy, Anthropology and Social Inquiry, Melbourne.

Langton, M. (1981) Urbanizing Aborigines: the social scientists' great deception, Social Alternatives, 2(2), pp. $16-22$.

MacDonald, G. (2000) Economies and personhood: demand sharing among the Wiradjuri of New South Wales, in: G. Wenzel, G. Hovelsrud-Broda \& N. Kishigami (Eds) The Social Economy of Sharing: Resource Allocation and Modern Hunter-Gatherers (Osaka: Senri Ethnological Studies).

Macklin, J. (2008) \$1.2 billion for closing the gap for Indigenous Australians, Australian Government Media Release, 13 May. Available at http://www.jennymacklin.fahcsia.gov.au/mediareleases/2008/Pages/ budget08_i-overarching_13may08.aspx

Marks, G. (2007) Income Poverty, Subjective Poverty and Financial Stress, Social Policy Research Paper No. 29 (Canberra: Department of Families, Community Services and Indigenous Affairs).

Memmott, P. \& Meltzer, A. (2005) Modelling social capital in a remote Australian Indigenous community, in: A. Dale \& J. Onyx (Eds) A Dynamic Balance: Social Capital and Sustainable Community Development (Vancouver: University of British Columbia Press).

Morgan, G. (2006) Unsettled Places: Aboriginal People and Urbanisation in New South Wales (Adelaide: Wakefield Press).

Mouw, T. (2006) Estimating the causal effect of social capital: a review of recent research, Annual Review of Sociology, 32, pp. 79-102.

Muir, K., Katz, I., Purcal, C., Patulny, R., Flaxman, S., Abello, D., Cortis, N., Thomson, C., Oprea, I., Wise, S., Edwards, B., Gray, M. \& Hayes, A. (2009) National Evaluation (2004-2008) of the Stronger Families and Communities Strategy 2004-2009, Occasional Paper No. 24 (Canberra: Australian Government Department of Families, Housing, Community Services and Indigenous Affairs).

Peel, M. (2003) The Lowest Rung: Voices of Australian Poverty (Cambridge: Cambridge University Press).

Peterson, N. \& Taylor, J. (2003) The modernising of the Indigenous domestic moral economy: kinship, accumulation and household composition, The Asia Pacific Journal of Anthropology, 4(1/2), pp. 105-122.

Prout, S. (2008) On the Move? Indigenous Temporary Mobility Practices in Australia, CAEPR Working Paper No. 48 (Canberra: Centre for Aboriginal Economic Policy Research, Australian National University).

Prout, S. (2011) Urban myths: exploring the unsettling nature of Aboriginal presence in and through a regional Australian town, Urban Policy and Research, 29(3), pp. 275-291.

Putnam, R. (1993) Making Democracy Work: Civic Traditions in Modern Italy (Princeton, NJ: Princeton University Press).

Quillian, L. \& Redd, R. (2008) Can social capital explain persistent racial poverty gaps?, in: A. Lin \& D. Harris (Eds) The Colors of Poverty: Why Racial and Ethnic Disparities Exist (New York: Russell Sage Foundation).

Reay, M. (1964) Aborigines Now: New Perspectives in the Study of Aboriginal Communities (Sydney: Angus and Robertson).

Rowley, C. (1970) Outcasts in White Australia (Canberra: Australian National University Press).

Rowse, T. (2000) Transforming the notion of the urban Aborigine, Urban Policy and Research, 18(2), pp. $171-190$.

Rowse, T. (2002) Indigenous Futures: Choice and Development for Aboriginal and Islander Australia (Sydney: University of New South Wales Press).

Saunders, P., Hill, T. \& Bradbury, B. (2008) Poverty in Australia: Sensitivity Analysis and Recent Trends, SPRC Report 4/08 (Sydney: Social Policy Research Centre, University of New South Wales).

Saunders, P. \& Naidoo, Y. (2009) Poverty, deprivation and consistent poverty, The Economic Record, 85(271), pp. 417-432.

Saunders, P., Naidoo, Y. \& Griffiths, M. (2007) Towards New Indicators of Disadvantage: Deprivation and Social Exclusion in Australia (Sydney: Social Policy Research Centre, University of New South Wales).

Schwab, J. (1995) The Calculus of Reciprocity: Principles and Implications for Aboriginal Sharing, CAEPR Discussion Paper No. 100 (Canberra: Centre for Aboriginal Economic Policy Research, Australian National University).

Stone, W. (2001) Measuring Social Capital: Towards a Theoretically Informed Measurement Framework for Researching Social Capital in Family and Community Life (Melbourne: Australian Institute of Family Studies). 
Stone, W. \& Hughes, J. (2002) Social Capital: Empirical Meaning and Measurement Validity (Melbourne: Australian Institute of Family Studies).

Taylor, J. (2006) Indigenous People in the West Kimberley Labour Market, CAEPR Working Paper No. 35 (Canberra: Centre for Aboriginal Economic Policy Research, Australian National University).

Taylor, J. (2009) Patterns and processes of Indigenous urbanization in Australia. Unpublished paper presented at Indigenous Urbanization in International Perspective Conference, Department of Native Studies and Geography, University of Saskatchewan.

Taylor, J. \& Hunter, B. (1997) Promoting growth in Indigenous employment: the role of the private sector, Australian Bulletin of Labour, 23(4), pp. 269-287.

Tynan, M. (2007) Shifting egalitarianisms and contemporary racism in rural Victorian football, The Australian Journal of Anthropology, 18(3), pp. 276-294.

van der Gaag, M. \& Webber, M. (2008) Measurement of individual social capital: questions, instruments and measures, in: I. Kawachi, S. Subramanian \& D. Kim (Eds) Social Capital and Health (New York: Springer).

Van Deth, J. (2003) Measuring social capital: orthodoxies and continuing controversies, International Journal of Social Research Methodology, 6(1), pp. 79-92.

Vinson, T. (2009a) Markedly Socially Disadvantaged Localities in Australia: Their Nature and Possible Remediation (Canberra: The Australian Department of Education, Employment and Workplace Relations).

Vinson, T. (2009b) The Origins, Meaning, Definition and Economic Implications of the Concept Social Inclusion/ Exclusion: Incorporating the Core Indicators Developed by the European Union and Other Illustrative Indicators that could Identify and Monitor Social Inclusion in Australia (Canberra: The Australian Department of Education, Employment and Workplace Relations).

Vurens van Es, R. \& Dockery, A. (2008) Indigenous Australians in the Labour Market: Exploring the Role of Social Capital, Centre for Labour Market Research Discussion Paper 08/03 (Perth: Curtin University of Technology).

Winter, I. (Ed.) (2000) Social Capital and Public Policy in Australia (Melbourne: Australian Institute of Family Studies).

Woolcock, M. (2001) The place of social capital in understanding social and economic outcomes, Isuma: Canadian Journal of Policy Research, 2(1), pp. 1-17.

Yamanoguchi, Y. (2010) Exploring ambiguity: Aboriginal identity negotiation in southwestern Sydney, Environment and Planning A, 42, pp. 285-299. 